\title{
An Evaluation of the Green Performance of Chinese New Energy Enterprises From the Perspective of Social Responsibility
}

Le Yang and Yue Zhang $\dagger$

Henan University of Engineering, Zhengzhou, Henan, China, 451191

†Corresponding author: Yue Zhang; zhangyue0106@163.com

\section{Nat. Env. \& Poll. Tech.} Website: www.neptjournal.com

Received: 12-05-2020

Revised: 27-08-2020

Accepted: 21-10-2020

Key Words:

Energy enterprises

Social responsibility

Green performance

\begin{abstract}
To evaluate the green performance of Chinese new energy enterprises, a performance evaluation system entailing four dimensions of social responsibility, management of liabilities, market-related responsibility, safety, and environmental responsibility was constructed. This system was subsequently applied to analyze and assess the green performances of 18 energy enterprises in China with their social responsibility. Results show that the green performances of most of the energy enterprises with social responsibility are hierarchically based. Specific countermeasures were proposed for promoting the health of energy enterprises and their sustainable development. These measures to be implemented by energy enterprises include establishing and perfecting systems for managing liabilities, sustaining the market, strengthening responsibility for security, and making diligent efforts to fulfil their environmental responsibilities.
\end{abstract}

\section{INTRODUCTION}

In recent years, from the 18th National Congress of the Communist Party of China, the first proposed "beautiful China", the integration of ecological civilization into the overall layout of "five in one", to the concept of "green mountains and green waters are golden mountains and silver mountains" entered the United Nations. The construction of ecological civilization has been elevated to an unprecedented height. Green development measures are taking root across China. Since the 19th National Congress of the Communist Party of China, China has entered a new era of socialism with Chinese characteristics. The economy has shifted from a high-speed growth stage to a high-quality development stage. The development concept of innovation, coordination, green, openness, and sharing is deeply rooted in the hearts of the people, and corporate social responsibility has also been included in the overall situation of deepening reform. The modern energy system is the essential requirement of the new era of energy development, and the new energy industry is also the main engine that promotes the high-quality development of China's economy.

As the economy enters the stage of high-quality development in China, stakeholders have higher expectations for the quality of social responsibility reports. Enterprises also need a standard to improve the quality of report compilation. The quality rating of social responsibility reports has become an important issue. The energy industry differs from other industries. The particularity of energy industry entails more risks relating to safety and security, with frequent occurrences of accidents (Yongtae \& Meir 2010). The energy industry supports China's economic and social development. However, environmental problems, wastage of resources, and security issues are common during the process of developing energy enterprises, leading to great security risks (Berman \& Bui 2001). Therefore, an evaluation of the green performance of energy enterprises with social responsibility will contribute to the promotion of sustainable development of energy enterprises and providing measurable indicators for evaluating corporate social responsibility (Nahyun et al. 2015). When energy enterprises promise to protect the environment and staff safety and save resources (Christopher et al. 2015), it will have great practical benefits to promote economic development, social stability and sustainable development.

This study takes China's new energy companies in the economic development transition stage as the research object and aims to establish a performance evaluation system that includes four dimensions of social responsibility, i.e. responsibility management, market-related responsibility, and safety and environmental responsibility. The system was subsequently used to analyze and evaluate the relationship between the green performance of China's 18 energy companies and their social responsibilities.

\section{PAST STUDIES}

The Academy of Management Journal devoted a thematic issue to corporate social responsibility and its editors identified research trends according to the papers published in this leading management journal (Wang et al. 2016). 
They observed an increase in the number of articles on corporate social responsibility over recent decades and how works examining a non-U.S. context or data have gained significance to the point that they are comparable in scale to those in the U.S. setting. Amos (2018) reviewed scholarly papers focused on corporate social responsibility in developing countries in international journals and found that those applied empirical research methodologies increased steadily in the period 2006-2014. Specifically, attention to corporate social responsibility is slowly gaining traction in the Middle East (Al-Abdin et al. 2018) and is a very highly probable topic in the literature of transition economies and emerging markets (Piepenbrink \& Nurmammadov 2015). Additionally, there was a noticeable concentration of papers in corporate social responsibility related journals, with the Journal of Business Ethics publishing as many articles as the nonspecialized journals.

At present, due to the differences in the understanding of the concept of corporate social responsibility by scholars, the academic circles mainly have two views on the connotation of corporate social responsibility. In general, there are two kinds of social responsibility in a broad sense and social responsibility in a narrow sense.

Most scholars believed that corporate social responsibility should be social responsibility in a broad sense. Carroll (1979) designed the corporate social responsibility pyramid. He divided corporate social responsibility into economic responsibility at the bottom level, legal responsibility at the second level, ethical responsibility at the third level, and charity responsibility at the final level. In 2010, the International Organization for Standardization (ISO) issued the ISO26000 Social Responsibility Guide, which covers nine aspects of social responsibility. The guide proposes that social responsibility should be fully integrated into the organization and integrated with the organization's strategy, philosophy, and planning. Lu \& Abeysekera (2014) also believed that the content of corporate social responsibility is multifaceted, but there are differences in corporate social responsibility in different industries in terms of legislative provisions. The Shenzhen Stock Exchange's Guidelines for Social Responsibility of Listed Companies issued in September 2006 pointed out that social responsibility in a broad sense. It refers to the comprehensive development of the country and society, the natural environment and resources, as well as shareholders, creditors, employees and customers.

In terms of corporate social responsibility evaluation research, most of the existing studies are limited to the evaluation process, and it is rare to discuss the corporate behaviour decision-making based on corporate social responsibility performance. The reason may be that it is difficult to obtain evaluation data, and the challenge of quantitative indicators
(Oliveira et al. 2018). Ferramosca \& Verona (2019) applied the combination of bibliometric analyses on a sample of 2,583 corporate social responsibility studies derived from Scopus (1973-2018). First, it is found that the interdisciplinary character of corporate social responsibility. Second, it recognized numerous topics in the history of corporate social responsibility research and demonstrated how these topics emerge, vanish, or become steady over time. Third, the patterns of evolution in terms of topics are reflected in scientific journal specialization and coauthorship collaborations. Finally, it provided the latest evaluation on the state of the art in this field, highlighting the hottest topics. Imed et al. (2020) re-examined this issue using a newly available comprehensive innovation database on 20 countries and found support for the view that corporate social responsibility performance fosters innovation. This effect of corporate social responsibility is reflected in corporate innovation through its environmental and social dimensions. Jesús et al. (2020) used the 101 projects as a reference and analyzed the application of sustainability and other factors in the corporate social responsibility index. He found that the commitment to corporate social responsibility can also be achieved by improving shareholders' profitability or return on equity and investors consider not only financial risks but also sustainability factors.

The study on the field of new energy has begun to increase, but the study on the social responsibility of new energy enterprises has only appeared in recent years. Tan (2015) took Longyuan Wind Power New Energy listed company as an example to analyze the current status of the corporate social responsibility, focusing on three aspects, i.e. social responsibility performance, social responsibility management and social responsibility reporting. The study on the level of corporate social responsibility information disclosure in the electricity, coal, water, food and beverage, petrochemical and plastic industries found that a sound governance environment, corporate scale, and profitability have a significant positive impact on corporate social responsibility information disclosure (Liu \& Zhang 2017). Han (2015) explored the impact of capacity utilization changes brought about by capacity reduction on the efficiency of industrial investment in China and found that the increase in capacity utilization has a positive effect on industrial investment efficiency, and it can also bring about non-surplus industries positive externalities.

\section{MATERIALS AND METHODS}

Green performance is evaluated based on externally conducted assessments of green development and its task index. Stakeholders of energy enterprises include 
shareholders, creditors, employees, the government, customers, the ecological environment, and communities (Du et al. 2020). This study drew on stakeholder theory applied to the actual situations of 18 energy enterprises listed in November 2016. A system for evaluating green performance was constructed based on the following four dimensions of social responsibility: liability management, market-related responsibility, safety, and environmental responsibility.

The system for evaluating the green performances of energy enterprises with their social responsibility comprised 4 level-one indicators, 12 level-two indicators, and 20 level-three indicators. The level-one indicators were the management of liabilities $(A)$, market-related responsibility $(B)$, security-related responsibility $(C)$, and environmental responsibility $(D)$. The level-three indicators were related to the basic score index. Each three-level indicator entailed either a score of five points or a score of zero, with 100 being the highest mark. The details of the indicators are shown in Table 1.

\section{RESULTS ANALYSIS}

\section{The Dimension of Liability Management}

Out of the 18 surveyed energy companies, 11 had established separate social responsibility management agencies. Therefore, each of these companies (PingZhuang Energy, Jizhong Energy, Xishan Coal and Electricity, Yanzhou

Table 1: The green performance evaluation index of social responsibility.

\begin{tabular}{|c|c|c|c|}
\hline $\begin{array}{l}\text { Level-one } \\
\text { indicators }\end{array}$ & $\begin{array}{l}\text { Level-two } \\
\text { indicators }\end{array}$ & Level-three indicators & Scoring criteria \\
\hline \multirow{5}{*}{$\begin{array}{l}\text { Liability } \\
\text { management } \\
\text { (A) }\end{array}$} & \multirow{5}{*}{$\begin{array}{l}\text { Institutions; } \\
\text { Report } \\
\text { continuity; } \\
\text { Report content }\end{array}$} & $\begin{array}{l}\text { Organization of social responsi- } \\
\text { bility management (A1) }\end{array}$ & $\begin{array}{l}\text { A score of } 5 \text { for the establishment of a special administrative agency; } \\
\text { otherwise, a score of } 0\end{array}$ \\
\hline & & $\begin{array}{l}\text { The number of pages of the social } \\
\text { responsibility report (A2) }\end{array}$ & $\begin{array}{l}\text { A score of } 5 \text { for numbers more than or equal to the average of } 33 \\
\text { pages; otherwise, a score of } 0\end{array}$ \\
\hline & & $\begin{array}{l}\text { Disclosure of the social responsi- } \\
\text { bility report for three consecutive } \\
\text { years (A3) }\end{array}$ & $\begin{array}{l}\text { A score of } 5 \text { for continuously issuing social responsibility reports for } \\
3 \text { consecutive years }\end{array}$ \\
\hline & & $\begin{array}{l}\text { Complete disclosure with inclu- } \\
\text { sion of negative information (A4) }\end{array}$ & $\begin{array}{l}\text { A score of } 5 \text { for disclosure of both positive and negative informa- } \\
\text { tion; otherwise, a score of } 0\end{array}$ \\
\hline & & $\begin{array}{l}\text { Comprehensibility of the social } \\
\text { responsibility report (A5) }\end{array}$ & $\begin{array}{l}\text { A score of } 5 \text { if the social responsibility report is comprehensible and } \\
\text { comparable; otherwise, a score of } 0\end{array}$ \\
\hline \multirow{5}{*}{$\begin{array}{l}\text { Market- } \\
\text { related } \\
\text { responsibility } \\
\text { (B) }\end{array}$} & \multirow{5}{*}{$\begin{array}{l}\text { Responsibility } \\
\text { score; } \\
\text { Employees' } \\
\text { basic rights and } \\
\text { interests; } \\
\text { The govern- } \\
\text { ment's respon- } \\
\text { sibility }\end{array}$} & Earnings per share (B1) & $\begin{array}{l}\text { A score of } 5 \text { for earnings more than or equal to average earnings for } \\
\text { the industry; otherwise, a score of } 0\end{array}$ \\
\hline & & $\begin{array}{l}\text { HeXun social responsibility report } \\
\text { score (B2) }\end{array}$ & $\begin{array}{l}\text { A score of } 5 \text { for a rating that is more than or equal to the overall } \\
\text { rating of the industry }\end{array}$ \\
\hline & & $\begin{array}{l}\text { Safeguarding of employees' basic } \\
\text { rights and interests (B3) }\end{array}$ & $\begin{array}{l}\text { A score of } 5 \text { for a labor contract and social security coverage rate } \\
\text { equal to } 100 \%\end{array}$ \\
\hline & & Taxes paid on schedule (B4) & A score of 5 for taxes paid on schedule; otherwise, a score of 0 \\
\hline & & $\begin{array}{l}\text { Disclosure of relevant data to } \\
\text { stakeholders (B5) }\end{array}$ & $\begin{array}{l}\text { A score of } 5 \text { for more detailed data disclosure; otherwise, a score of } \\
0\end{array}$ \\
\hline \multirow{5}{*}{$\begin{array}{l}\text { Security-re- } \\
\text { lated respon- } \\
\text { sibility }(\mathrm{C})\end{array}$} & \multirow{5}{*}{$\begin{array}{l}\text { Security } \\
\text { certification; } \\
\text { Safety concept; } \\
\text { Accident rate }\end{array}$} & $\begin{array}{l}\text { Certification of safety system } \\
\text { (C1) }\end{array}$ & A score of 5 for passing authentication; otherwise, a score of 0 \\
\hline & & Occupational safety training (C2) & A score of 5 for occupational safety training; otherwise, a score of 0 \\
\hline & & $\begin{array}{l}\text { Mortality rate per million tons } \\
\text { (C3) }\end{array}$ & $\begin{array}{l}\text { A score of } 0 \text { for a rate that is above the average rate of the industry; } \\
\text { otherwise, a score of } 5\end{array}$ \\
\hline & & Safety administration $(\mathrm{C} 4)$ & A score of 5 for investments in rectification; otherwise, a score of 0 \\
\hline & & $\begin{array}{l}\text { Disclosure of relevant information } \\
\text { on safe production (C5) }\end{array}$ & $\begin{array}{l}\text { A score of } 5 \text { for detailed disclosure on safe production, investments, } \\
\text { and other relevant information }\end{array}$ \\
\hline \multirow{5}{*}{$\begin{array}{l}\text { Environmen- } \\
\text { tal } \\
\text { responsibility } \\
\text { (D) }\end{array}$} & \multirow{5}{*}{$\begin{array}{l}\text { Environmental } \\
\text { certification; } \\
\text { Conservation of } \\
\text { resources; } \\
\text { Environmental } \\
\text { protection }\end{array}$} & $\begin{array}{l}\text { Environmental management } \\
\text { system certification (D1) }\end{array}$ & $\begin{array}{l}\text { A score of } 5 \text { for certification; a score of } 0 \text { for failure to obtain certifi- } \\
\text { cation or lack of disclosure. }\end{array}$ \\
\hline & & $\begin{array}{l}\text { Environmental protection con- } \\
\text { sciousness (D2) }\end{array}$ & $\begin{array}{l}\text { A score of } 5 \text { for green initiatives and investments; otherwise, a score } \\
\text { of } 0\end{array}$ \\
\hline & & Coal gangue utilization rate (D3) & $\begin{array}{l}\text { A score of } 5 \text { if this rate exceeds the average rate for the industry; } \\
\text { otherwise, a score of } 0\end{array}$ \\
\hline & & Mine water utilization rate (D4) & $\begin{array}{l}\text { A score of } 5 \text { if this rate exceeds the average rate for the industry; } \\
\text { otherwise, a score of } 0\end{array}$ \\
\hline & & Recovery rate (D5) & $\begin{array}{l}\text { A score of } 5 \text { if this rate exceeds the average rate for the industry; } \\
\text { otherwise, a score of } 0\end{array}$ \\
\hline
\end{tabular}


Coal, Shanghai Datun Energy, Shanxi Coal International, Yunnan Coal Energy, China Shenhua Energy, Haohua Energy, Shanxi Lu'an Environmental Energy, and China Coal Energy) scored 5 points. The remaining seven companies each obtained a score of 0 because they had not established an agency for managing social responsibility.

The average number of pages in social responsibility reports for the 18 energy enterprises was 34 . Seven of these companies issued reports that were more than 34 pages in length. These companies were Jizhong Energy, Yanzhou Coal, Shanxi Coal International, Yunnan Coal Energy, China Shenhua Energy, Shanxi Lu' an Environmental Energy, and China Coal Energy whose social responsibility reports were respectively 49, 88, 47, 36, 116, 57, and 53 pages long. Consequently, these companies each scored 5 points, whereas the remaining 11 companies each scored 0 .

All 18 energy companies released social responsibility reports for three consecutive years 2013, 2014, and 2015. Consequently, all of the companies scored 5 points.

Whereas all 18 companies announced positive developments, few enterprises released any negative information. However, the social responsibility reports of three companies contained both positive news as well as more detailed negative information relating to their productive and operational processes, such as accidents in coal mines and the death toll from accidents. These three companies, namely China Shenhua Energy, Haohua Energy, and Shanxi Lu' an Environmental Energy each scored 5 points, whereas the remaining 15 companies each scored 0 .

Eight of the enterprises produced social responsibility reports that were relatively easy to understand compared with those of other companies because they contained a large number of tables and charts and provided comparisons and analyses of extensive historical data (Claudiu et al. 2014). These eight companies were Jizhong Energy, Yanzhou Coal, Shanxi Coal International, Yunnan Coal Energy, China Shenhua Energy, Haohua Energy, Shanxi Lu' an Environmental Energy, and China Coal Energy. Therefore, each of these companies scored 5 points, while the remaining 10 companies each scored 0 .

\section{The Dimension of Market-Related Responsibility}

EPS, which refers to the ratio of the after-tax profit to the total number of shares, is an important financial indicator for measuring the profitability of enterprises. In 2015, the average EPS value in the energy industry was 0.29 RMB. Of the 18 companies, six demonstrated EPS values that were above the industry's average. These companies were Jizhong Energy, Lanhua Sci-Tech Venture, China Shenhua Energy, Haohua Energy, Shanxi Lu'an Environmental Energy, and
Yitai Coal, and their respective EPS values were 0.32, 0.46, $2.26,0.31,0.52$, and 1.06 . Whereas each of these companies scored 5 points, the remaining 12 companies, with lower than average EPS values, each scored 0 .

The Hexun social responsibility report score is a relative authority score developed by HeXun that depends on the responsibility of an enterprise's shareholders, employees, suppliers, customers, and the environment. The shareholders' responsibility encompasses corporate profitability, solvency and returns and is measured using a series of financial and accounting indicators. In 2015, the energy industry's average social responsibility score was 16.05 . The scores of five companies, namely Lanyan Holding, Xishan Coal and Electricity, Yanzhou Coal, China Shenhua Energy, and Shanxi Lu'an Environmental Energy were above the industry's average score at 51.49, 17.10, 16.10, 27.89, and 16.07, respectively. Therefore, these companies each scored 5 points, whereas the remaining 13 companies, whose scores were below the industry average, each scored 0 .

The labour contract signing rate and the social security coverage rate for all 18 companies were at the $100 \%$ level. Consequently, all of the enterprises scored 5 points. All of the 18 energy companies paid their taxes on schedule. Therefore they all scored 5 points. Four out of the 18 companies disclosed relevant data to stakeholders. These companies, namely Jizhong Energy, Yanzhou Coal, China Shenhua Energy, and Shanxi Lu' an Environmental Energy each scored 5 points, whereas the remaining 14 companies each scored 0 .

\section{The Dimension of Security Responsibility}

Out of the social responsibility reports issued by the 18 surveyed energy companies, only that of China Shenhua Energy disclosed that the company's security system was certified. Therefore, this was the only company that scored 5 points, whereas each of the 17 other companies scored 0 .

All 18 energy companies scored 5 points for occupational safety training. In 2015 , the mortality rate per million tons of coal was 0.162 within the energy industry. All 18 of the energy enterprises demonstrated mortality rates below this average and therefore scored 5 points.

Only two companies, the Shenhuo Group and Yitai Coal did not disclose information on their security costs and rectification of security risks. Therefore, these companies both scored 0 , whereas all of the remaining 16 companies, which disclosed security governance information, scored 5 points.

Ten companies, namely Pingzhuang Energy, Jizhong Energy, Lanyan Holding, Xishan Coal and Electricity, Yanzhou Coal, Shanxi Coal International, Yunnan Coal Energy, China Shenhua Energy, Shanxi Lu' an Environmental Energy, and China Coal Energy disclosed more detailed 
information than other companies regarding the management of safe production, safe production inputs and other safetyrelated data. Each of these 10 companies scored 5 points, whereas the remaining eight companies each scored 0 .

\section{The Dimension of Environmental Responsibility}

The social responsibility reports of the 18 companies revealed that five companies, namely Jizhong Energy, Xishan Coal and Electricity, Yanzhou Coal, China Shenhua Energy, and Shanxi Lu' an Environmental Energy had obtained certification of their environmental management systems. Therefore, these five companies each scored 5 points, whereas the remaining 13 companies each scored 0 , as their environmental management systems had not been certified.

Only one company, Yitai Coal, scored 0, as it did not disclose its environmental philosophy or any investments relating to environmental protection. The other 17 companies, which provided information on their environmental protection concepts, and also disclosed the purposes and quantities of their environmental investments, all scored 5 points. Data on the utilization of coal gangue and mine water, and recovery rates, were extracted from the companies' social responsibility reports as well as from their annual financial reports and official websites. The specific data compiled are shown in Table 2.
For coal enterprises within China's energy industry, the standard rate of coal gangue utilization is $75 \%$. The coal gangue utilization rates of seven out of the 18 energy companies were below $75 \%$. Therefore, these companies, namely Pingzhuang Energy, the Shenhuo Group, Lanhua Sci-Tech Venture, Shanghai Datun Energy, China Shenhua Energy, Shanxi Lu' an Environmental Energy, and Yitai Coal, each scored 0 . All of the remaining 11 companies evidenced ratios above $75 \%$ and therefore scored 5 points.

Again taking the example of coal enterprises, the standard rate of mine water utilization was $70 \%$. Five of the companies (Pingzhuang Energy, China Shenhua Energy, Shanxi Lu' an Environmental Energy, Xinji Energy, and Yitai Coal) evidenced mine water utilization rates below $70 \%$ and accordingly scored 0 . The remaining 13 companies, which evidenced rates over $70 \%$, each scored 5 points.

The standard recovery rate for the coal industry is $75 \%$. Among the 18 energy companies, the Shenhuo Group, Lanyan Holding, Shanghai Datun Energy, and Kailuan Clean Coal had recovery rates below the industry's standard and their scores were therefore 0 . The rates of the remaining 14 companies were above this standard, so they all scored 5 points.

Tables 3 and 4 show the specific index scores of the 18 surveyed energy enterprises. Whereas Table 3 shows the

Table 2: Utilization ratios for coal gangue and mine water and recovery rates.

\begin{tabular}{|c|c|c|c|c|c|}
\hline $\begin{array}{l}\text { S. } \\
\text { No. }\end{array}$ & $\begin{array}{l}\text { Company } \\
\text { code }\end{array}$ & Corporate name & $\begin{array}{l}\text { Coal gangue utilization } \\
\text { ratio }(\%)\end{array}$ & $\begin{array}{l}\text { Mine water utilization ra- } \\
\text { tio }(\%)\end{array}$ & Recovery rate $(\%)$ \\
\hline 1 & 000780 & Pingzhuang Energy & 60.00 & 30.03 & 77.14 \\
\hline 2 & 000933 & The Shenhuo Group & 71.50 & 91.00 & 45.00 \\
\hline 3 & 000937 & Jizhong Energy & 80.50 & 77.40 & 94.00 \\
\hline 4 & 000968 & Lanyan Holding & 86.38 & 83.00 & 68.00 \\
\hline 5 & 000983 & Xishan Coal and Electricity & 76.00 & 100.0 & 91.13 \\
\hline 6 & 600123 & Lanhua Sci-Tech Venture & 74.00 & 72.00 & 78.90 \\
\hline 7 & 600188 & Yanzhou Coal & 100.0 & 92.35 & 81.62 \\
\hline 8 & 600508 & Shanghai Datun Energy & 49.60 & 76.00 & 57.00 \\
\hline 9 & 600546 & Shanxi Coal International & 80.00 & 80.00 & 83.00 \\
\hline 10 & 600792 & Yunnan Coal Energy & 92.00 & 90.50 & 75.00 \\
\hline 11 & 600997 & Kailuan Clean Coal & 79.15 & 84.10 & 50.47 \\
\hline 12 & 601088 & China Shenhua Energy & 20.14 & 67.50 & 89.19 \\
\hline 13 & 601101 & Haohua Energy & 95.30 & 87.00 & 85.63 \\
\hline 14 & 601666 & Pingdingshan Tianan Coal Mining & 100.0 & 80.00 & 85.00 \\
\hline 15 & 601699 & Shanxi Lu'an Environmental Energy & 56.00 & 68.00 & 100.0 \\
\hline 16 & 601898 & China Coal Energy & 98.80 & 75.40 & 89.10 \\
\hline 17 & 601918 & Xinji Energy & 97.00 & 66.52 & 79.60 \\
\hline 18 & 900948 & Yitai Coal & 66.40 & 41.00 & 80.00 \\
\hline
\end{tabular}


Table 3: Green performance scores of the top-ranked nine surveyed companies.

\begin{tabular}{|llllllllll|}
\hline $\begin{array}{l}\text { Evaluation } \\
\text { indicator }\end{array}$ & $\begin{array}{l}\text { Ping- } \\
\text { zhuang } \\
\text { Energy }\end{array}$ & $\begin{array}{l}\text { Shen- } \\
\text { huo } \\
\text { Group }\end{array}$ & $\begin{array}{l}\text { Jizhong } \\
\text { Energy }\end{array}$ & $\begin{array}{l}\text { Lanyan } \\
\text { Holding }\end{array}$ & $\begin{array}{l}\text { Xishan Coal } \\
\text { and } \\
\text { Electricity }\end{array}$ & $\begin{array}{l}\text { Lanhua } \\
\text { Sci-Tech } \\
\text { Venture }\end{array}$ & $\begin{array}{l}\text { Yanzhou } \\
\text { Coal }\end{array}$ & $\begin{array}{l}\text { Shanghai } \\
\text { Datun } \\
\text { Energy }\end{array}$ & $\begin{array}{l}\text { Shanxi } \\
\text { Coal Inter- } \\
\text { national }\end{array}$ \\
\hline $\mathrm{A}_{1}$ & 5 & 0 & 5 & 0 & 5 & 0 & 5 & 5 & 5 \\
$\mathrm{~A}_{2}$ & 0 & 0 & 5 & 0 & 0 & 0 & 5 & 0 & 5 \\
$\mathrm{~A}_{3}$ & 5 & 5 & 5 & 5 & 5 & 5 & 5 & 5 & 5 \\
$\mathrm{~A}_{4}$ & 0 & 0 & 0 & 0 & 0 & 0 & 0 & 0 & 0 \\
$\mathrm{~A}_{5}$ & 0 & 0 & 5 & 0 & 0 & 0 & 5 & 0 & 5 \\
$\mathrm{~B}_{1}$ & 0 & 0 & 5 & 0 & 0 & 5 & 0 & 0 & 0 \\
$\mathrm{~B}_{2}$ & 0 & 0 & 0 & 5 & 5 & 0 & 5 & 0 & 0 \\
$\mathrm{~B}_{3}$ & 5 & 5 & 5 & 5 & 5 & 5 & 5 & 5 & 5 \\
$\mathrm{~B}_{4}$ & 5 & 5 & 5 & 5 & 5 & 5 & 5 & 5 & 5 \\
$\mathrm{~B}_{5}$ & 0 & 0 & 5 & 0 & 0 & 0 & 5 & 0 & 0 \\
$\mathrm{C}_{1}$ & 0 & 0 & 0 & 0 & 0 & 0 & 0 & 0 & 0 \\
$\mathrm{C}_{2}$ & 5 & 5 & 5 & 5 & 5 & 5 & 5 & 5 & 5 \\
$\mathrm{C}_{3}$ & 5 & 5 & 5 & 5 & 5 & 5 & 5 & 5 & 5 \\
$\mathrm{C}_{4}$ & 5 & 0 & 5 & 5 & 5 & 5 & 5 & 5 & 5 \\
$\mathrm{C}_{5}$ & 5 & 0 & 5 & 5 & 5 & 0 & 5 & 0 & 5 \\
$\mathrm{D}_{1}$ & 0 & 0 & 5 & 0 & 5 & 0 & 5 & 0 & 0 \\
$\mathrm{D}_{2}$ & 5 & 5 & 5 & 5 & 5 & 5 & 5 & 5 & 5 \\
$\mathrm{D}_{3}$ & 0 & 0 & 5 & 5 & 5 & 0 & 5 & 0 & 5 \\
$\mathrm{D}_{4}$ & 0 & 5 & 5 & 5 & 5 & 5 & 5 & 5 & 5 \\
$\mathrm{D}_{5}$ & 5 & 0 & 5 & 0 & 5 & 5 & 5 & 0 & 5 \\
Total score & 50 & 35 & 85 & 55 & 70 & 50 & 85 & 45 & 70 \\
${ }$ & & & 5 & & & 5 & & 5 & 5 \\
\hline
\end{tabular}

Table 4: Green performance scores of the nine lower-ranked surveyed companies.

\begin{tabular}{|c|c|c|c|c|c|c|c|c|c|}
\hline $\begin{array}{l}\text { Evaluation } \\
\text { indicator }\end{array}$ & $\begin{array}{l}\text { Yunnan } \\
\text { Coal } \\
\text { Energy }\end{array}$ & $\begin{array}{l}\text { Kailuan } \\
\text { Clean } \\
\text { Coal }\end{array}$ & $\begin{array}{l}\text { China } \\
\text { Shenhua } \\
\text { Energy }\end{array}$ & $\begin{array}{l}\text { Haohua } \\
\text { Energy }\end{array}$ & $\begin{array}{l}\text { Pingdin-gshan } \\
\text { Tianan Coal } \\
\text { Mining }\end{array}$ & $\begin{array}{l}\text { Shanxi Lu'an } \\
\text { Environmental } \\
\text { Energy }\end{array}$ & $\begin{array}{l}\text { China } \\
\text { Coal } \\
\text { Energy }\end{array}$ & $\begin{array}{l}\text { Xinji } \\
\text { Energy }\end{array}$ & Yitai Coal \\
\hline $\mathrm{A}_{1}$ & 5 & 0 & 5 & 5 & 0 & 5 & 5 & 0 & 0 \\
\hline $\mathrm{A}_{2}$ & 5 & 0 & 5 & 0 & 0 & 5 & 5 & 0 & 0 \\
\hline $\mathrm{A}_{3}$ & 5 & 5 & 5 & 5 & 5 & 5 & 5 & 5 & 5 \\
\hline $\mathrm{A}_{4}$ & 0 & 0 & 5 & 5 & 0 & 5 & 0 & 0 & 0 \\
\hline $\mathrm{A}_{5}$ & 5 & 0 & 5 & 5 & 0 & 5 & 5 & 0 & 0 \\
\hline $\mathrm{B}_{1}$ & 0 & 0 & 5 & 5 & 0 & 5 & 0 & 0 & 5 \\
\hline $\mathrm{B}_{2}$ & 0 & 0 & 5 & 0 & 0 & 5 & 0 & 0 & 0 \\
\hline $\mathrm{B}_{3}$ & 5 & 5 & 5 & 5 & 5 & 5 & 5 & 5 & 5 \\
\hline $\mathrm{B}_{4}$ & 5 & 5 & 5 & 5 & 5 & 5 & 5 & 5 & 5 \\
\hline $\mathrm{B}_{5}$ & 0 & 0 & 5 & 0 & 0 & 5 & 0 & 0 & 0 \\
\hline $\mathrm{C}_{1}$ & 0 & 0 & 5 & 0 & 0 & 0 & 0 & 0 & 0 \\
\hline $\mathrm{C}_{2}$ & 5 & 5 & 5 & 5 & 5 & 5 & 5 & 5 & 5 \\
\hline $\mathrm{C}_{3}$ & 5 & 5 & 5 & 5 & 5 & 5 & 5 & 5 & 5 \\
\hline $\mathrm{C}_{4}$ & 5 & 5 & 5 & 5 & 5 & 5 & 5 & 5 & 0 \\
\hline $\mathrm{C}_{5}$ & 5 & 0 & 5 & 0 & 0 & 5 & 5 & 0 & 0 \\
\hline$D_{1}$ & 0 & 0 & 5 & 0 & 0 & 5 & 0 & 0 & 0 \\
\hline $\mathrm{D}_{2}$ & 5 & 5 & 5 & 5 & 5 & 5 & 5 & 5 & 0 \\
\hline $\mathrm{D}_{3}$ & 5 & 5 & 0 & 5 & 5 & 0 & 5 & 5 & 0 \\
\hline $\mathrm{D}_{4}$ & 5 & 5 & 0 & 5 & 5 & 0 & 5 & 0 & 0 \\
\hline $\mathrm{D}_{5}$ & 5 & 0 & 5 & 5 & 5 & 5 & 5 & 5 & 5 \\
\hline Total score & 70 & 45 & 90 & 70 & 50 & 85 & 70 & 45 & 35 \\
\hline
\end{tabular}


nine top-ranked companies, Table 4 shows the remaining nine lower-ranked companies in no particular order, listed according to their stock code numbers. The scores in these two tables reflect the green performance evaluations of the 18 surveyed companies with social responsibility.

The application of this classification scheme to the scores of the 18 surveyed energy companies resulted in the following groups. The first group of achievers comprised four companies: Jizhong Energy, Yanzhou Coal, China Shenhua Energy, and Shanxi Lu'an Environmental Energy. The group of leaders comprised five companies: Xishan Coal and Electricity, Shanxi Coal International, Yunnan Coal Energy, Haohua Energy, and China Coal Energy. The third group of pursuers comprised seven companies: Pingzhuang Energy, Lanyan Holding, Lanhua Sci-Tech Venture, Shanghai Datun Energy, Kailuan Clean Coal, Pingdingshan Tianan Coal Mining, and Xinji Energy. The final group of starters consisted of two companies, namely the Shenhuo Group and Yitai Coal.

When the scores for green performance ratings of corporate social responsibility were combined, the scores of Jizhong Energy, Yanzhou Coal, China Shenhua Energy, and Shanxi Lu'an Environmental Energy were all above 80. Of these companies, China Shenhua Energy had 90 points in total, demonstrating the best green performance relating to social responsibility. Two of the companies, the Shenhuo Group and Yitai Coal, attained only 35 points, indicating that their green performance relating to social responsibility was poor and that there was an urgent need for these companies to establish and develop improved systems for managing social responsibility. The performances of five companies, namely Xishan Coal and Electricity, Shanxi Coal International, Yunnan Coal Energy, Haohua Energy, and China Coal Energy were relatively good, but these companies still need to make sustained efforts. Seven companies, namely Pingzhuang Energy, Lanyan Holding, Lanhua Sci-Tech Venture, Shanghai Datun Energy, Kailuan Clean Coal, Pingdingshan Tianan Coal Mining, and Xinji Energy demonstrated relatively poor performances, indicating that they need to attach more importance to the development of social responsibility and to act in practical ways to promote its enforcement and enhance their performance levels.

\section{DISCUSSION}

\section{The Dimension of Liability Management}

From the perspective of liability management, whereas energy companies release social responsibility reports in time, most are unwilling to disclose negative information. The quality of social responsibility reports issued by energy companies was uneven in terms of the number of pages of the reports, their content, and their readability ( $\mathrm{Li}$ et al. 2019). Moreover, they demonstrated striking contrasts in terms of the integrity of their content.

The results for the $A_{1}$ indicator (establishment of an organization for managing social responsibility) showed that 11 out of the 18 surveyed companies have performed relatively well, with more than half of the energy enterprises having prioritized the establishment of agencies for managing social responsibility. However, seven of the 18 companies still needed to prioritize the establishment of agencies to manage social responsibility.

The results for the $\mathrm{A}_{2}$ indicator (number of pages of social responsibility reports) revealed the extent of disclosure of energy companies in their social responsibility reports, with the reports of seven companies exceeding 34 pages. Whereas the report content on social responsibility for these seven companies was good, as reflected in their scores, the remaining 11 companies scored lower for their report content, indicating that they needed to devote more attention to their social responsibility reports.

For the $\mathrm{A}_{3}$ indicator (continuous disclosure of social responsibility reports for three consecutive years), the results indicated that each of the 18 surveyed companies scored 5 points, and this performance needs to be sustained.

The results for the $\mathrm{A}_{4}$ indicator (complete disclosure, including negative information) indicated that the information reported by most of the energy enterprises was incomplete. Only three companies, namely China Shenhua Energy, Haohua Energy, and Shanxi Lu' an Environmental Energy scored 5 points, as they comprehensively disclosed positive as well as negative information. Thus, the information disclosed by most of the energy enterprises was incomplete. This situation indicates an urgent need for improvement.

For the $\mathrm{A}_{5}$ indicator (comprehensibility of the responsibility reports), the results showed that eight of the surveyed companies performed relatively well. Thus, more than half of the energy companies attached less importance to their social responsibility reports.

\section{The Dimension of Market-Related Responsibility}

From the perspective of market-related responsibility, energy companies did well in protecting their employees' basic rights and interests and in paying taxes on schedule. However, most energy companies did not publish comprehensive data and information to all concerned stakeholders.

For the $\mathrm{B}_{1}$ indicator, the results showed that the EPS of six companies exceeded the current year's average EPS of 0.29, and the EPS of China Shenhua Energy was the highest at 2.26. Twelve companies had below-average EPS values, with that of Xinji Energy being especially low at -0.11 . These 
findings indicate that the economic benefits of the energy enterprises were not very promising.

The results for the $\mathrm{B}_{2}$ indicator (the HeXun social responsibility report score) showed that the majority of companies (13) scored below the industry average, with only one-third (5) of the companies demonstrating scores above the average score for the industry.

For the $\mathrm{B}_{3}$ indicator (safeguarding employees' basic rights and interests), the results showed that all of the surveyed companies scored 5 points. The labour contract signing rate and social security coverage reached the $100 \%$ level, indicating that energy companies performed well in terms of safeguarding their employees' basic rights and interests.

The results for the $\mathrm{B}_{4}$ indicator (taxes paid on schedule) indicated that all of the surveyed firms scored 5 points, indicating that the 18 companies performed well in terms of paying their taxes and that they did so in a timely way.

For the $\mathrm{B}_{5}$ indicator (disclosure of relevant data to stakeholders), the results showed that only four companies ( $22 \%$ of the sample) made detailed disclosures to each stakeholder. The disclosure of the remaining 14 companies to stakeholders was inadequate.

\section{The Dimension of Responsibility for Security}

From the perspective of responsibility for safety, energy enterprises diligently conducted safety training for their employees, and the accident mortality rate was controlled at a level below the average. Most companies attached great importance to safety governance, which included investments to improve safety and rectification of safety risks, with more than half of the companies also disclosing relevant safety data. However, less attention was given to certification of the safety system, so increased efforts to develop certified safety systems are necessary.

For the $\mathrm{C}_{1}$ indicator (certification of safety systems), the results showed that only China Shenhua Energy had obtained certification of their safety system and that none of the other energy companies had obtained this certification. Therefore, strengthening the authentication work for security systems is an urgent priority.

The results for the $\mathrm{C}_{2}$ indicator (occupational safety training of employees), showed that all of the companies scored 5 points, indicating that these 18 companies conducted occupational safety training for their employees. Although the number and scale of training sessions differed, energy companies performed quite well in protecting their employees' basic rights and interests.

For the $\mathrm{C}_{3}$ indicator (mortality rate per million tons), the results showed that all of the companies scored 5 points.
The mortality rates per million tons for all 18 companies were lower than the industry's average rate, indicating that energy enterprises had sufficient controls in place relating to accidental mortalities.

For the $\mathrm{C}_{4}$ indicator (safety administration), the results showed that 16 companies ( $89 \%$ of the sample) invested in safety costs relating to production, management activities, and rectification of hidden dangers impacting on safety. Thus, most of the energy enterprises attached great importance to the work of safety management.

For the $\mathrm{C}_{5}$ indicator (disclosure of relevant information on safety production), the results indicated that 10 companies performed relatively well. However, disclosure of safe production management, safe production inputs, and other related data information was incomplete.

\section{The Dimension of Environmental Responsibility}

In terms of environmental responsibility, most coal companies performed relatively poorly in the area of certification of their environmental management systems. The utilization rates of coal gangue and mine water and the recovery rate of half of the companies were above the industry standard. Nevertheless, these rates were below the industry's standard for many enterprises. Of the 18 companies, China Shenhua Energy attained the highest score, but the utilization ratios of coal gangue and mine water were inadequate. Consequently, energy enterprises need to pay more attention to protecting the environment.

For the $\mathrm{D}_{1}$ indicator (environmental management system certification), the results showed that only five companies had obtained certification of their environmental management systems. Consequently, energy enterprises need to accelerate their efforts to obtain certification of their environmental management systems.

The results for the $\mathrm{D}_{2}$ indicator (environmental awareness) indicated that most of the energy enterprises demonstrated awareness of the need for environmental protection, with only one company, Yitai Coal, obtaining a score of 0 . This finding indicates that China's energy enterprises are performing reasonably well in the area of environmental awareness. However, there is still a need to strengthen efforts in the area of environmental protection.

For the $\mathrm{D}_{3}$ indicator (the coal gangue utilization ratio), the results showed that 11 companies demonstrated ratios that exceeded the industry standard. Of these companies, Yanzhou Coal and Pingdingshan Tianan Coal Mining had the highest coal gangue utilization ratios. The remaining seven companies had ratios below the industry standard, with the ratio of China Shenhua Energy being the lowest. 
The results for the $\mathrm{D}_{4}$ indicator (the mine water utilization ratio) showed that the ratios for 13 companies were above the industry standard, with that of Xishan Coal and Electricity being the highest. The ratios of the remaining five companies were below the industry standard, and that of Pingzhuang Energy was the lowest.

The results for the $\mathrm{D}_{5}$ indicator (the recovery rate) indicated that the recovery rates of 14 companies were above the industry standard, with that of Shanxi Lu' an Environmental Energy being the highest. The recovery rates of the remaining four companies were below the industry standard, and that of the Shenhuo Group was the lowest.

\section{CONCLUSIONS}

A system for evaluating the green performance of energy enterprises was constructed based on four dimensions of social responsibility: liability management, market-related responsibility, responsibility for security, and environmental responsibility. The green performances of 18 energy enterprises with their social responsibility were subsequently analyzed and evaluated.

Based on the application of an established classification standard and the scores of the 18 surveyed energy companies, four companies were identified as achievers. These companies were Jizhong Energy, Yanzhou Coal, China Shenhua Energy, and Shanxi Lu'an Environmental Energy. Although China Shenhua Energy demonstrated the best green performance, it still needs to make considerable efforts to improve the utilization ratios of coal gangue and mine water.

Most of the energy companies' green performances relating to social responsibility were categorized at a medium level, with significant variations among them. The energy companies that demonstrated excellent green performances relating to social responsibility should make efforts to sustain their advantages, while companies whose green performance was the poor need to prioritize and strengthen their social responsibility to promote their health along with their benign and sustainable development.

\section{ACKNOWLEDGEMENT}

This study was supported by the Humanity and Social Science Youth Foundation of the Ministry of Education of China (Grant No.18YJC630254), Henan Young Teachers Program of China (2019GGJS238), and Henan Soft Science Project of China (202400410377).

\section{REFERENCES}

Al-Abdin, A., Roy, T. and Nicholson, J. D. 2018. Researching corporate social responsibility in the Middle East: The current state and future directions. Corporate Social Responsibility and Environmental Management, 25(1): 47-65.

Amos, G.J. 2018. Researching corporate social responsibility in developing-countries context: A systematic review of the literature. International Journal of Law and Management, 60: 284-310.

Berman, E. and Bui, T.M. 2001. Environmental regulation and labor demand: evidence from the south coast air basin. Journal of Public Economics, 79(5): 264-295.

Carroll, A.B. 1979. A three-dimensional conceptual model of corporate performance. Academy of Management Review, 4(4): 497-505.

Christopher, S.G., Robert, C.A. and Gregory, L. 2015. The environmental and economic effects of regional bio-energy policy in the southeastern U.S. Energy Policy, 85(11): 334-346.

Claudiu, C. 2014. Environmental efficiency of investments in renewable energy: comparative analysis at macroeconomic level. Renewable and Sustainable Energy Reviews, 3(7): 554-564.

Du, Y.C., Wang R.X. 2020. Impact of corporate governance ability on capital gains in mixed-ownership enterprises. Transformations in Business \& Economics, 19(2): 92-113.

Ferramosca, S. and Verona, R. 2019. Framing the evolution of corporate social responsibility as a discipline (1973-2018): A large-scale scientometric analysis. Corporate Social Responsibility and Environmental Management, 27(3): 1-26.

Han, G.G. 2015. Analysis of the effect of capacity reduction on China's industrial investment efficiency. Management Modernization, 35(6): 28-30.

Imed, C.A, Boushra, H.A., Hatem, R.B. and Samir, S.C. 2020. Does corporate social responsibility influence corporate innovation? International evidence. Emerging Markets Review, 278(2): 498-513.

Jesús, M.F., Gracia, R.M. and Carmen, R.S. 2020. Corporate social responsibility and crowd-funding: The experience of the colectual platform in empowering economic and sustainable projects. Sustainability, 12(13): 5251

Li, W., Li, Z., Liu, S. and Huang, M. 2019. The economic-environmental impacts of China's action plan for soil pollution control. Sustainability, 11(8): 2322-2334.

Liu, X. and Zhang, C. 2017. Corporate governance, social responsibility information disclosure, and enterprise value in China. Journal of Cleaner Production, 142: 1075-1084.

Lu, Y. and Abeysekera, I. 2014. Stakeholders' power, corporate characteristics, and social and environmental disclosure: evidence from China. Journal of Cleaner Production, 64: 426-436.

Nahyun, K., Jon, J.M. and Hai, Y. 2015. Environmental pressure and the performance of foreign firms in an emerging economy. Journal of Business Ethics, 4(6): 1-16.

Oliveira, R., Zanella, A. and Camanho, A.S. 2019. The assessment of corporate social responsibility: The construction of an industry ranking and identifification of potential for improvement. European Journal of Operational Research, 278(2): 498-513.

Piepenbrink, A. \& Nurmammadov, E. 2015. Topics in the literature of transition economies and emerging markets. Scientometrics, 102(3): 2107-2130.

Tan, J.S. 2015. Research on social responsibility of new energy enterprises. Modern Corporate Culture, 5: 74-75.

Wang, H., Tong, L., Takeuchi, R. and George, G. 2016. Corporate social responsibility: An overview and new research directions. Academy of Management Journal, 59(2): 534-544.

Yongtae, K. and Meir, S. 2010. Do corporations invest enough in environmental responsibility? Journal of Business Ethics, 105(3): 114-129. 